\title{
Uptake of Chromium by Portulaca Oleracea from Soil: Effects of Organic Content, pH, and Sulphate Concentration
}

\author{
Ayman Alyazouri, ${ }^{1}$ Roger Jewsbury, ${ }^{1}$ Hassan Tayim, ${ }^{2}$ Paul Humphreys, ${ }^{3}$ \\ and Mohammad H. Al-Sayah $\mathbb{D}^{2}$ \\ ${ }^{1}$ Department of Chemical Sciences, University of Huddersfield, Queensgate, West Yorkshire HD13DH, UK \\ ${ }^{2}$ Department of Biology, Chemistry and Environmental Sciences, American University of Sharjah, P. O. Box 26666, Sharjah, UAE \\ ${ }^{3}$ Department of Biological Sciences, University of Huddersfield, Queensgate, West Yorkshire HD13DH, UK
}

Correspondence should be addressed to Mohammad H. Al-Sayah; malsayah@aus.edu

Received 28 February 2020; Revised 21 May 2020; Accepted 25 May 2020; Published 10 June 2020

Academic Editor: Amaresh K. Nayak

Copyright (c) 2020 Ayman Alyazouri et al. This is an open access article distributed under the Creative Commons Attribution License, which permits unrestricted use, distribution, and reproduction in any medium, provided the original work is properly cited.

Phytoextraction is an effective and environment-friendly approach for remediation of soil polluted with toxic metals. Portulaca oleracea is a potential hyperaccumulator of $\mathrm{Cr}(\mathrm{VI})$ from polluted soil. In this study, the effect of soil organic content, $\mathrm{pH}$, and sulphate concentration on phytoextraction of $\mathrm{Cr}(\mathrm{VI})$ using Portulaca oleracea was investigated. Seedlings of Portulaca oleracea were grown in soils with (i) three organic content compositions, (ii) six levels of $\mathrm{pH}$, and (iii) six concentrations of sulphate salts; all were irrigated with $\mathrm{Cr}(\mathrm{VI})$ solutions at $200 \mathrm{ppm}$ concentration. Chromium concentration in different tissues of plants was monitored under the variant conditions. Results indicated that the uptake of $\mathrm{Cr}(\mathrm{VI})$ by Portulaca oleracea is favoured at (i) low organic content soil $(0.42 \%)$, (ii) slightly alkaline $\mathrm{pH}$ range $(\sim 8)$, and (iii) with sulphate concentration in the range of $300-600 \mathrm{ppm}$.

\section{Introduction}

Portulaca oleracea is a succulent plant (family Portulacaceae) native to the Mediterranean area, but it grows in several parts of the world from India to Australia and North America. The plant is a self-compatible annual weed that grows fast and can reach up to $40 \mathrm{~cm}$ in height. Usually, it grows along the ground with smooth stems, alternate leaves, and taproots that enable it to tolerate poor soils and dry areas. $P$. oleracea is commonly known as purslane and it is used in food, where it is added to soups and salads, and in folk medicine remedies including antimicrobial, antidiabetic, anti-inflammatory, and anticancer properties $[1,2]$.

The process of phytoextraction requires the uptake of heavy metal pollutants from soil or water (by the roots) and then translocating them to the above-ground parts [3]. The process requires that the plant has the potential to accumulate a large amount of the heavy metal relative to its dry weight. Also, for the plant to be an effective candidate for the phytoextraction technique, it needs to accumulate more than
$0.1 \%(1000 \mathrm{mg} / \mathrm{kg})$ of its weight of chromium, cobalt, copper, or nickel metals and more than $1.0 \%$ of zinc or manganese metals [4]. P. oleracea has been shown to extract both organic pollutants and heavy metal ions. Okuhata et al. [5] have investigated its ability to remove bisphenol derivatives from aquatic solution and it was able to remove $97 \%$ of $4,4^{\prime}$ thiodiphenol from the culture within four days. Meanwhile, a significant number of studies focused on the ability of $P$. oleracea to extract heavy metals from contaminated soil or water [6-14]. These studies show that the plant has a high tolerance for many metals, including $\mathrm{Cd}$ (II), $\mathrm{Cu}$ (II), $\mathrm{Cr}$ (III), $\mathrm{Cr}(\mathrm{VI}), \mathrm{Fe}(\mathrm{III}), \mathrm{Mn}(\mathrm{II}), \mathrm{Ni}$ (II), $\mathrm{Pb}(\mathrm{II})$, and $\mathrm{Zn}(\mathrm{II})$ ions, and has the ability to extract them to its roots from either soil or aqueous solutions with variant capacities. It was, however, established that $P$. oleracea is a hyperaccumulator for $\mathrm{Cr}(\mathrm{VI})$; a hyperaccumulator plant can extract the metal at concentrations ten times (at least) higher than their concentrations in the soil or wastewater. We have previously reported that $P$. oleracea is tolerant to high concentrations of $\mathrm{Cr}(\mathrm{VI})$ in soil up to $400 \mathrm{mg} / \mathrm{kg}[6,7]$. The plant was able to 
extract the metal (soil concentration of $200 \mathrm{mg} / \mathrm{kg}$ ) into its roots with a total concentration exceeding $2000 \mathrm{mg} / \mathrm{kg}$ and a bioaccumulation factor (BAF) greater than 10 . BAF is the ratio of the concentration of metal in dry roots $(\mathrm{mg} / \mathrm{kg}$ dry weight) to the concentration of metal in dry soil or wastewater ( $\mathrm{mg} / \mathrm{kg}$ or $\mathrm{ppm})$.

It is believed that $P$. oleracea is able to tolerate the stress of high $\mathrm{Cr}(\mathrm{VI})$ concentration in the growth medium through two pathways: (i) the production and accumulation of proline to maintain osmotic balance and (ii) the activation of antioxidant enzymes (such as the peroxidase) to combat the oxidative stress of the metals $[12,15]$. It was shown that the plant is able to reduce more than $97 \%$ of $\mathrm{Cr}(\mathrm{VI})$ accumulated in its roots to the less toxic $\mathrm{Cr}$ (III) and then translocates it to the shoots and the leaves with a translocation factor (TF) of 0.4. TF is the ratio of the concentration of metal in dry shoots to its concentration in dry roots. Therefore, $P$. oleracea has great potential for remediation of chromium-contaminated environmental media and detoxification of the metal [7].

$\mathrm{Cr}(\mathrm{VI})$ is classified by the World Health Organization as a human carcinogen, and it is known to cause damage to respiratory tract tissues, kidneys, liver, and skin $[16,17]$. The high toxicity of $\mathrm{Cr}(\mathrm{VI})$ is attributed to its strong oxidizing effect on the intracellular proteins and nucleic acids since hexavalent chromium compounds $\left(\mathrm{H}_{2} \mathrm{CrO}_{4}, \mathrm{HCrO}_{4}^{-}\right.$, $\mathrm{CrO}_{4}^{2-}$, and $\mathrm{Cr}_{2} \mathrm{O}_{7}^{2-}$ ) have high solubility and permeability of cell membrane $[18,19]$. The trivalent chromium, however, exists mainly as chromium oxide $\left(\mathrm{Cr}_{2} \mathrm{O}_{3}\right)$ or chromium hydroxide $\left(\mathrm{Cr}(\mathrm{OH})_{3}\right)$; both species have low solubility and are biologically unavailable. Therefore, the ability of $P$. oleracea to extract the metal from the soil is dependent on the speciation of the metal and its bioavailability which, in turn, is dependent on several factors including (i) the organic content, (ii) the $\mathrm{pH}$, and (iii) the presence of sulphate ions in the soil [18-21]. Herein, we report on the results of investigating these factors on the uptake of $\mathrm{Cr}(\mathrm{VI})$ by $P$. oleracea from contaminated UAE soil.

\section{Results and Discussion}

2.1. Effect of Soil Organic Content. The presence of organic matter in the soil affects the speciation and the mobility of chromium metal ions. The degradation of organic compounds in the soil leads to (i) the increase of dissolved organic carbon and (ii) the formation of the oxidized chelating ligands of metal ions, such as the carboxylic acids, which also lowers the $\mathrm{pH}$ of the soil [22-24]. The former enhances the reduction of $\mathrm{Cr}$ (VI) to $\mathrm{Cr}$ (III), which is less biologically available, while the latter increases the adsorption and the retention of the metal species to the soil (vide infra). Besides, the increase in the organic content of the soil helps in the bioreduction of $\mathrm{Cr}$ (VI) to $\mathrm{Cr}$ (III) by microorganisms that thrive in organic-rich soil. Due to these factors, the uptake of chromium by the plant is expected to decrease as the organic content of the soil increases $[19,25]$.

To investigate the effect of the organic content of soil on the uptake of $\mathrm{Cr}(\mathrm{VI})$ by P. oleracea, three sets of the plants (five pots in each set) were grown in soils with organic content of $0.42 \%, 17.5 \%$, and $35.0 \%$, respectively, and were irrigated with
$\mathrm{Cr}(\mathrm{VI})$ as sodium chromate. The plants were harvested and analysed for total chromium while the soils were sampled and analysed for $\mathrm{Cr}(\mathrm{VI})$ and total chromium concentrations. Figure 1 exhibits the concentrations of chromium in the plant tissues and $\mathrm{Cr}(\mathrm{VI})$ in the soil upon the change in the organic content of the soil. A significant decrease in the uptake of $\mathrm{Cr}(\mathrm{VI})$ by $P$. oleracea was observed in both roots and shoots as the organic matter content of soil increased $(p<0.01)$. In the dry roots, $P$. oleracea accumulated $\sim 3,000 \mathrm{mg} / \mathrm{kg}$ of chromium in the presence of $0.42 \%$ of organic matter, but this concentration decreased to $530 \mathrm{mg} / \mathrm{kg}$ at $17.5 \%$ and to below $180 \mathrm{mg} /$ $\mathrm{kg}$ at $35 \%$ organic matter. This change was also concomitant with a decrease in the bioaccumulation factor (Figure 1(c)) of $\mathrm{Cr}(\mathrm{VI})$ from 27 (at $0.42 \%$ ) to 5.5 (at $35.0 \%$ ) and a decrease of the concentration of $\mathrm{Cr}(\mathrm{VI})$ available in the soil (Figure 1(b)) from $107 \mathrm{mg} / \mathrm{kg}$ (at $0.42 \%$ ) to $21 \mathrm{mg} / \mathrm{kg}$ (at $35.0 \%$ ). BAF of total chromium (Figure 1(c)) followed a parallel trend to that of $\mathrm{Cr}(\mathrm{VI})$ but to a lower extent indicating that chromium uptake by the plant is mainly of $\mathrm{Cr}(\mathrm{VI})$. The concentration of total chromium (Figure 1(b)) in the soil shows that as the organic content increased, more chromium remained in the soil although the concentration of $\mathrm{Cr}(\mathrm{VI})$ decreased. This can be attributed mainly to the reduction of $\mathrm{Cr}(\mathrm{VI})$ to $\mathrm{Cr}$ (III) due to the oxidation of organic compounds. Yet, it is worth noting that the presence of other metals such as $\mathrm{Mn}(370 \pm 40 \mathrm{mg} / \mathrm{Kg})$ and $\mathrm{Fe}(4800 \pm 500 \mathrm{mg} / \mathrm{Kg})$ can contribute to the reduction of $\mathrm{Cr}(\mathrm{VI})$. However, although the concentration of these metals decreased as the organic content of the soil increased, the amount of total chromium, and hence $\mathrm{Cr}$ (III), in the soil increased. Thus, this indicates that the organic compounds are major contributors for reducing $\mathrm{Cr}(\mathrm{VI})$ to $\mathrm{Cr}(\mathrm{III})$.

These results indicate that the increase in the organic content of the soil has two major effects. First, it enhances the growth of the plant and thus it increases its dry weight (Figure 2) which in turn leads to a decrease in both the concentration of metal in the plant and the bioaccumulation factor. Second, the increase of organic content in the soil leads to the reduction of the soluble $\mathrm{Cr}(\mathrm{VI})$ to the less soluble $\mathrm{Cr}$ (III), which is less available to the plant especially at the $\mathrm{pH}$ range of the used soil ( 7.9) (vide infra). At low organic content $(0.42 \%)$, there was an insignificant increase in the dry weight of the plant (Figure 2) and in the reduction of the metal to $\mathrm{Cr}$ (III) in the soil. As the concentration of the organic matter increased to $17.5 \%$, the dry weight of the plant increased significantly in the control sample but there was no significant increase in the weight of the plants irrigated with the metal solution. This is attributed to the negative effect of the metal uptake on plant growth. At this concentration of the organic content, the available $\mathrm{Cr}(\mathrm{VI})$ in the soil was at a moderate level of $\sim 61 \mathrm{mg} / \mathrm{kg}$ for uptake by the plant. When the concentration of the organic matter increased to $35 \%$, however, the dry weight of the plant increased significantly in both the control and the metal-irrigated samples while the available $\mathrm{Cr}(\mathrm{VI})$ in the soil was at very low levels of $21 \mathrm{mg} / \mathrm{kg}$. Therefore, organic matter has an indirect impact on the chromium uptake by $P$. oleracea by reducing the concentration of the bioavailable $\mathrm{Cr}(\mathrm{VI})$ in the soil.

These results are in agreement with those of [9] which have shown that the uptake of chromium by $P$. oleracea from 


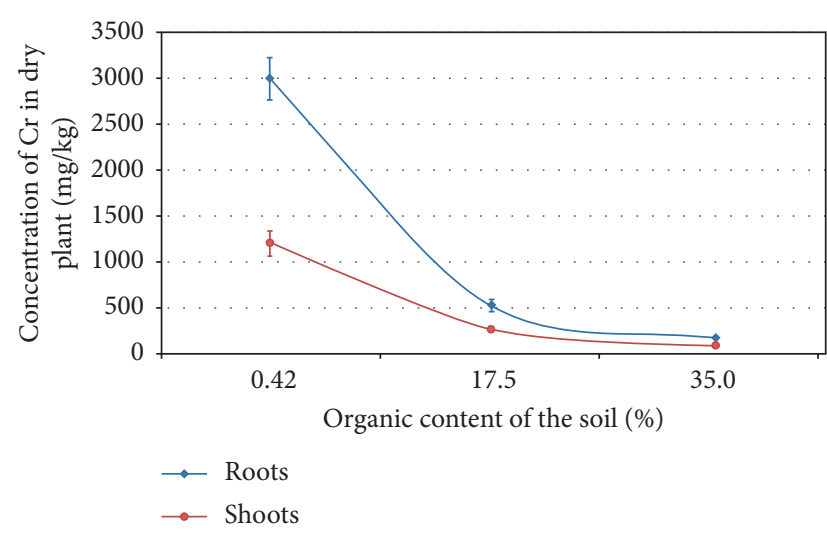

(a)

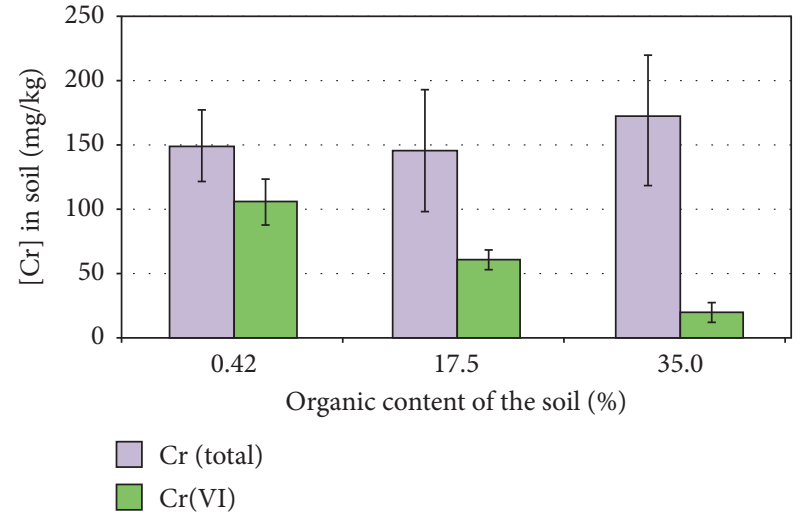

(b)

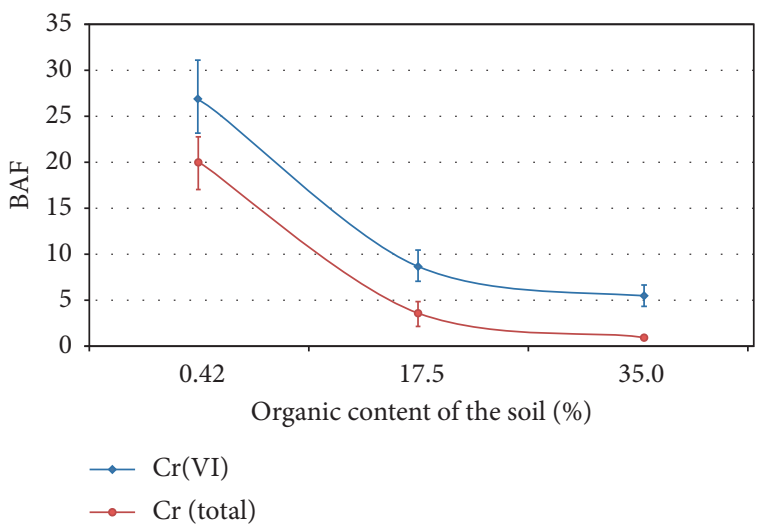

(c)

Figure 1: (a) Concentrations of total chromium in both shoots and roots of Portulaca oleracea, (b) concentrations of total chromium and $\mathrm{Cr}(\mathrm{VI})$ in the soil, and (c) change in bioaccumulation factors of total chromium and $\mathrm{Cr}(\mathrm{VI})$ at different levels of organic content in soil (mean of five replicates \pm SE, $95 \%$ CLs).

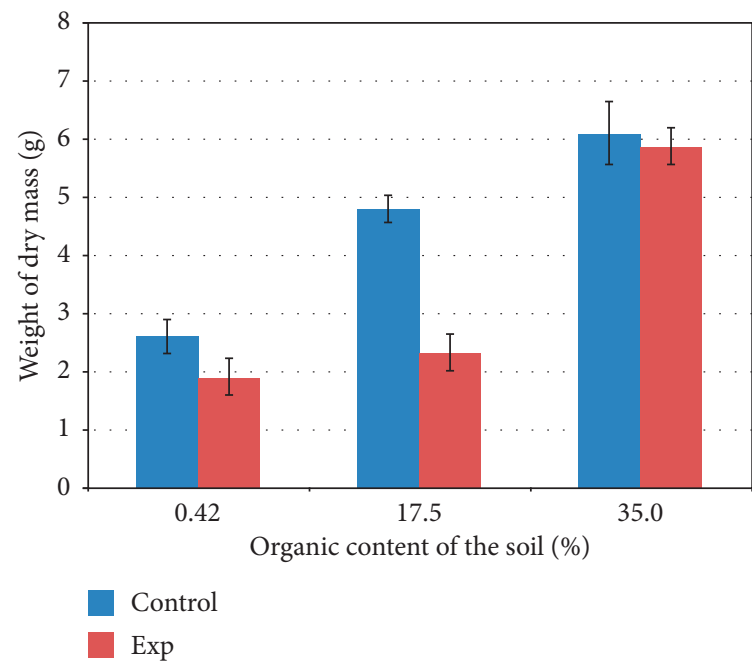

Figure 2: Weight of dry shoots of $P$. oleracea at different levels of organic matter in soil in both control and experimental samples (mean of five replicates \pm SE, 95\% CLs).

a sludge, with $51 \%$ organic matter content and $70 \mathrm{mg} / \mathrm{kg} \mathrm{Cr}$ concentration, was at $45.1 \mathrm{mg} / \mathrm{kg}$ and a BAF of 0.89 . Reports on the uptake of metals have shown that the increase in the organic content of soil had lowered the uptake of Cr by studied plants, as the addition of organic matter to soil increases the reduction of $\mathrm{Cr}(\mathrm{VI})$ to $\mathrm{Cr}$ (III) and, hence, lowers its bioavailability [22, 24, 26-28].

2.2. Effect of SoilpH. The $\mathrm{pH}$ of the soil has a major effect on the geochemical properties of chromium by affecting the chemical speciation of the metal and the adsorption ability of the soil. In acidic soils and solutions $(\mathrm{pH}<4), \mathrm{Cr}(\mathrm{III})$ mostly exists as $\left[\mathrm{Cr}\left(\mathrm{H}_{2} \mathrm{O}\right)_{6}\right]^{3+}$, which is converted to $\mathrm{Cr}(\mathrm{OH})_{3}$ as the $\mathrm{pH}$ increases. $\mathrm{Cr}(\mathrm{VI})$ may exist as soluble sodium chromate $\left(\mathrm{Na}_{2} \mathrm{CrO}_{4}\right)$ or the sparingly soluble calcium chromate $\left(\mathrm{CaCrO}_{4}\right)$ in neutral-alkaline soils but in acidic conditions $(\mathrm{pH}<5), \mathrm{HCrO}_{4}^{-}$becomes the dominant form. As the concentration of $\mathrm{Cr}(\mathrm{VI})$ increases in highly acidic aqueous systems, $\mathrm{HCrO}_{4}^{-}$ion is converted to the dichromate ion $\left(\mathrm{Cr}_{2} \mathrm{O}_{7}^{2-}\right)[19,29-32]$.

The $\mathrm{pH}$ also affects the adsorbing ability of the soil for different metal species. At acidic $\mathrm{pH}(<4)$, the cation-exchange sites in the soil are saturated with the protons which leads to desorption and release of the metal ions into solution, which makes them more available to the plants. Meanwhile, the acidic soil has a higher adsorption affinity for anions such as $\mathrm{CrO}_{4}^{2-}$ and $\mathrm{HCrO}_{4}^{-}$, which will be less 
available for plant uptake. At basic pHs, however, the metalbinding sites in the soil will be activated and the soil will have higher adsorption affinity for positive metal cations while the anions will be released. Therefore, the most suitable $\mathrm{pH}$ range for removal of $\mathrm{Cr}(\mathrm{VI})$ species from the soil is at the neutral-alkaline range where the dominant species for chromium, the chromate anion $\left(\mathrm{CrO}_{4}^{2}\right)$, has the maximum mobility $[19,25]$.

Our previous studies on the uptake of chromium from UAE soil by $P$. oleracea showed that, at $\mathrm{pH}=7.9 \pm 0.1$, the optimum concentration for the maximum uptake efficiency of the plant is at $200 \mathrm{mg} / \mathrm{kg}$ of chromium [7]. Thus, in the current study, the uptake of chromium by $P$. oleracea was monitored as the $\mathrm{pH}$ of the soil increased from 6.0 to 9.0 at a $\mathrm{Cr}(\mathrm{VI})$ loading of $200 \mathrm{mg} / \mathrm{kg}$ in the soil. The effect of the $\mathrm{pH}$ of the soil on the plant growth was also monitored in the presence and the absence of chromium metal. Therefore, six groups of pots were prepared at six $\mathrm{pH}$ levels $(6.0,7.0,7.3$, $7.6,8.0,9.0 \pm 0.1)$ of the soil (10\% organic content) and were irrigated with chromate solution $(200 \mathrm{ppm})$ while another set of six groups at the same $\mathrm{pH}$ levels were irrigated with deionised water.

The observed results (exhibited in Figure 3) show that both chromium concentration in the roots and the BAF exhibited a sigmoidal relationship with the change in $\mathrm{pH}$ with significant increases between the mean values at $\mathrm{pH}$ 6.0, 7.3 , and $9.0(p<0.01)$ while the concentration of total chromium in the soil remained relatively similar. Below $\mathrm{pH}$ 7.0, where the $\mathrm{HCr}_{2} \mathrm{O}_{4}^{-}$is the dominant species, there were no significant changes $(p>0.05)$ in root chromium concentrations. A similar trend was observed when the $\mathrm{pH}$ exceeded $\mathrm{pH} 7.6$ with no significant increase $(p>0.05)$ in root chromium content beyond this point and the amount of chromium in the roots exceeded $1300 \mathrm{mg} / \mathrm{kg}$ in dry biomass. Within this $\mathrm{pH}$ range (7.0-7.9), chromium primarily exists as the chromate species $\left(\mathrm{CrO}_{4}^{2-}\right)$; this implies that $P$. oleracea prefers to accumulate the metal in the form of $\mathrm{CrO}_{4}^{2-}$ at neutral-to-alkaline $\mathrm{pH}$ rather than $\mathrm{HCr}_{2} \mathrm{O}_{4}^{-}$which dominates at slightly acidic pHs $(<7)[33,34]$. BAF of total chromium followed also a similar trend with the highest values $(>8)$ at $\mathrm{pH}$ range $7.0-7.9$. Yet, the concentration of chromium in the soil did not change significantly over the $\mathrm{pH}$ range (Figure 3(b)) which further supports that speciation of $\mathrm{Cr}(\mathrm{VI})$ to the chromate species enhances BAF at high pHs. On the other hand, the uptake of chromium did not have a significant impact $(p>0.05)$ on the growth of the plants as indicated by the recovered dry biomass between $\mathrm{pH}$ 6.0 and $\mathrm{pH} 8.0$ (Figure 4). However, a significant decrease $(p<0.05)$ in the dry biomass was observed when the $\mathrm{pH}$ was raised to 9.0 in both the control and chromium-treated plants. This decrease suggests that the observed impact on growth was due to the basic $\mathrm{pH}$, which affects the growth of the roots, rather than the accumulation of chromium.

The accumulation of chromium in the shoots of $P$. oleracea, on the other hand, exhibited a different response with increasing $\mathrm{pH}$ as compared to that in the roots (Figure 3(a)). In this case, the concentration increased linearly with the increase in the $\mathrm{pH}$, unlike the sigmoidal change that was observed for the concentration of the metal in the roots (Figure 3(a)). This increase of chromium concentration in the shoots from $262 \mathrm{mg} / \mathrm{kg}$ at $\mathrm{pH} 6$ to $813 \mathrm{mg} / \mathrm{kg}$ at pH 9 was accompanied with a TF (Figure 3(c)) ranging from 2.45 to 2.56 , respectively, without being significantly affected by the change in the $\mathrm{pH}$. These results suggest that the translocation of the metal from the roots to the shoots is not dependent on the speciation of chromium in the soil at different pHs. This is further supported by our previous findings [7] that more than $97 \%$ of $\mathrm{Cr}(\mathrm{VI})$ accumulated in roots is reduced to $\mathrm{Cr}$ (III) before its translocation to the shoots as a chelated cation [35].

These results are in agreement with previous studies that have shown that there is a significant effect of $\mathrm{pH}$ on the uptake of chromium by nutrient crop plants, fungi, and microorganisms [36-39]. Shewry and coworkers [40] reported a $100 \%$ increase in chromium uptake by barley seedlings from hydroponic culture as the $\mathrm{pH}$ increased from 3.0 to 6.7 , where the chromate anion is the dominate species. These results seem inline also with a proposed mechanism for uptake of chromium by different plants using the same transport processes of the sulphate anion due to the structural similarity between the two anions in charge, shape, and size $[12,33,34,41-43]$.

2.3. Effect of Sulphate Concentration in Soil. In light of this proposed mechanism for the uptake of chromium by $P$. oleracea, we investigated the effect of sulphate concentration in soil on the uptake of chromium. Sulphate anion was introduced at five different concentrations $(0,300,600,1200$, and $1800 \mathrm{ppm}$ with $\mathrm{Cr}(\mathrm{VI})$ at $200 \mathrm{ppm}$ in each solution) into five groups of identical soil (15\% organic content) pots each containing four seedlings of $P$. oleracea (five replicates); a sixth group was irrigated with deionised water as a control.

The results exhibited in Figure 5(a) show that the concentration of chromium in roots increased significantly $(p<0.01)$ to over $1300 \mathrm{mg} / \mathrm{kg}$ as the concentration of sulphate increased from $0.0 \mathrm{ppm}$ to $300 \mathrm{ppm}$. There was no further change in the uptake of $\mathrm{Cr}(\mathrm{VI})$ as the concertation of sulphate increased to $600 \mathrm{ppm}(p>0.05)$. However, when the concentration of sulphate exceeded $600 \mathrm{ppm}$, chromium concentration in roots decreased significantly $(p<0.01)$ to $\sim 840 \mathrm{mg} / \mathrm{kg}$. The change in the bioaccumulation factor (Figure 5(b)) of chromium followed a similar trend to that of metal concentration, reaching a maximum value of 7.2 at sulphate concentration of 300-600 ppm. However, there was no significant change in the concentrations of chromium in the shoots (Figure 5(a)) as the concentration of the sulphate in the irrigating solution changed from 0 to $1800 \mathrm{ppm}$ $(p>0.05)$. A similar trend was also observed for the change in the TF of chromium (Figure 5(b)) from the roots to the shoots.

Previous studies reported similar results for the effect of sulphate concentration on the uptake of chromate. For example, studies on duckweeds (Spirodela polyrhiza and Lemna minor) showed even a better matching trend to our results where the uptake of chromium by the duckweed was enhanced at low concentration of sulphates (1.25 ppm) and diminished at high concentration $(960 \mathrm{ppm})$. The observed 


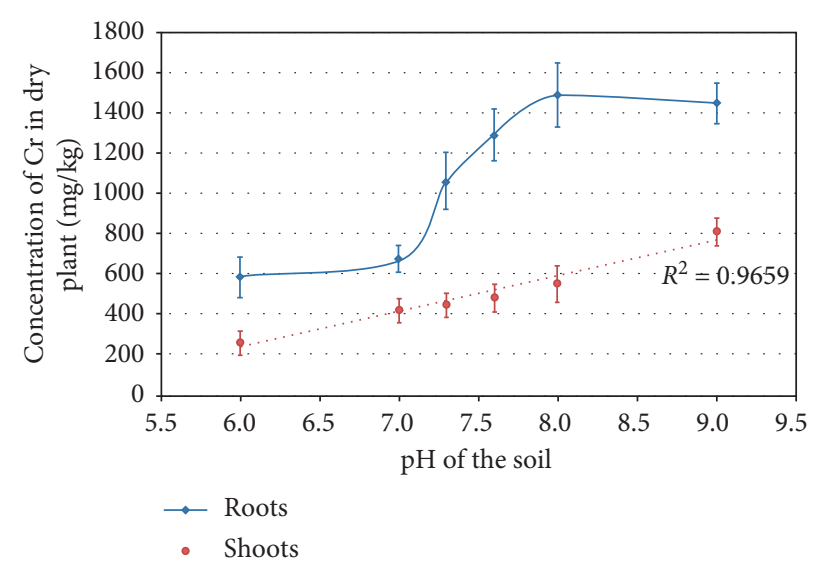

(a)

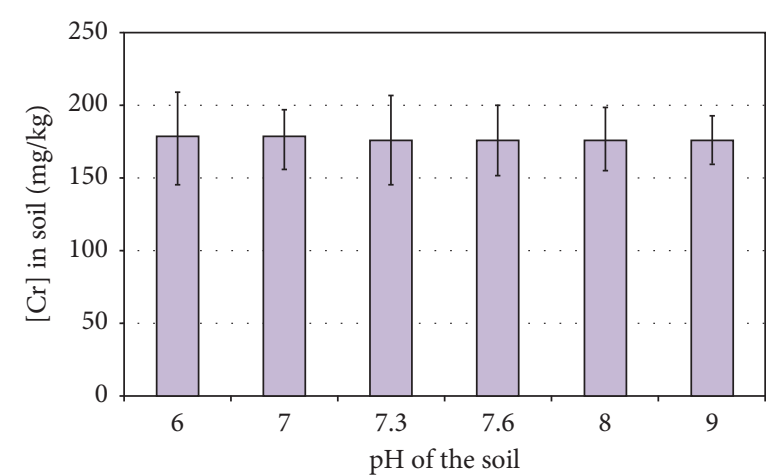

(b)

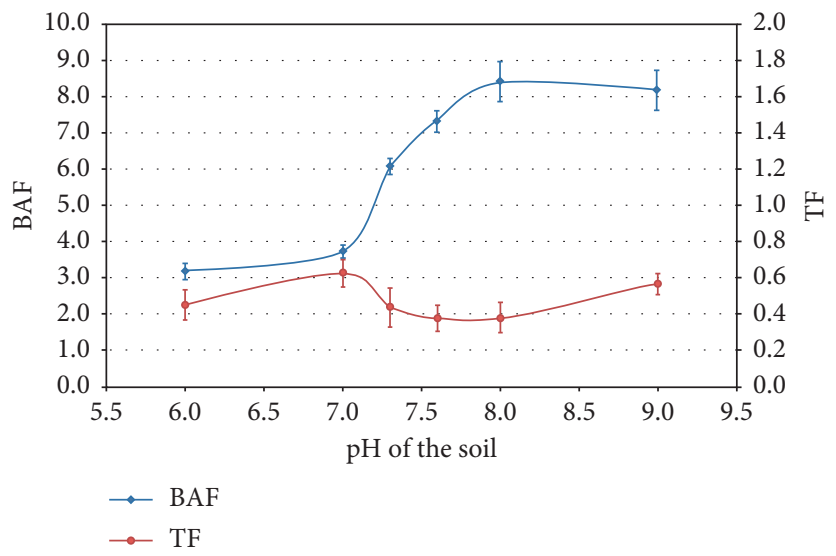

(c)

FIgURe 3: Change in concentration of total chromium (a) in the roots and shoots and (b) in the soil; (c) change in bioaccumulation and translocation factors of $P$. oleracea versus $\mathrm{pH}$ of the soil (mean of six replicates $\pm \mathrm{SE}, 95 \% \mathrm{CLs}$ ).

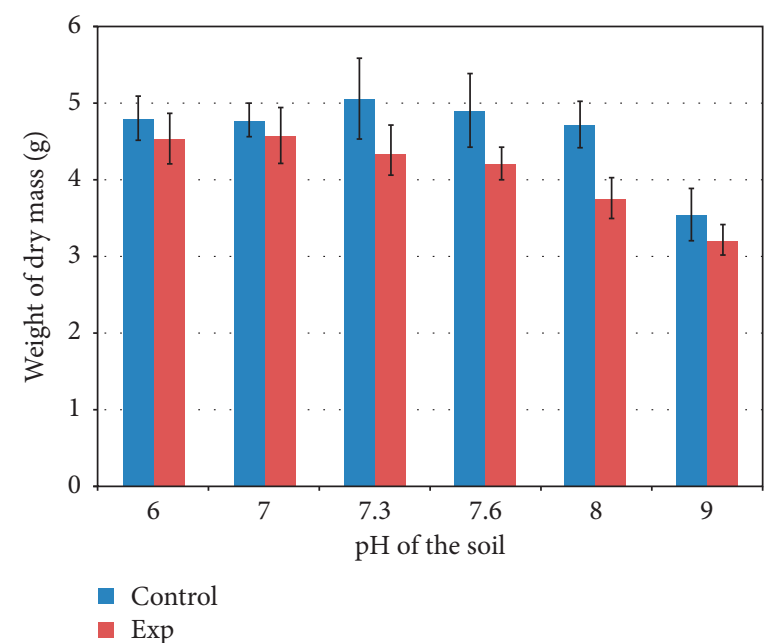

FIgure 4: Change in the weight of dry biomass of $P$. oleracea in the absence (control) and presence (Exp) of chromium as the pH of soil increases (mean of six replicates $\pm \mathrm{SE}, 95 \% \mathrm{CLs}$ ).

results were attributed to the uptake of chromate through the sulphate transporters but with a higher affinity to the chromate ions. The report concludes that the number of sulphate transporters on the roots is correlated with the sulphate concentration where, at high concentrations of the sulphate, the anion competes to bind to the transporters over the chromate [44]. Recent reports by de Oliveira et al. showed that the addition of sulphate at moderate 


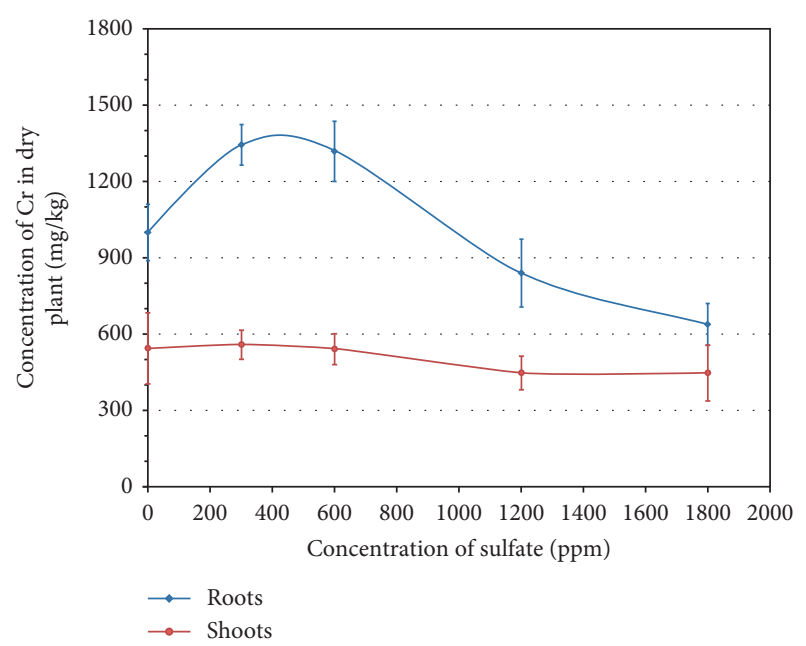

(a)

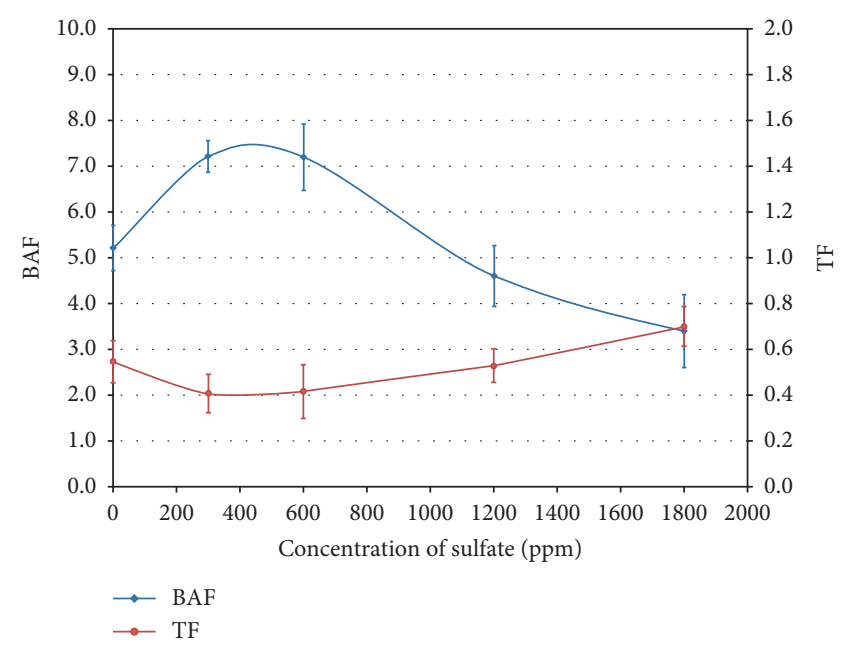

(b)

Figure 5: (a) Change in concentration of chromium in the roots and shoots and (b) change in bioaccumulation and translocation factors of $P$. oleracea at different concentrations of sulphate in the soil (mean of six replicates \pm SE, 95\% CLs).

concentrations ( $\sim 125-250 \mathrm{ppm})$ to the hydroponic system of Pteris vittata enhanced its uptake of chromium by $1.3-7.8$ folds. However, the translocation of the metal to the fronds was only slightly enhanced $[33,34]$.

Therefore, our results further support the hypothesis that the chromate anion is taken up by $P$. oleracea using the cellular carriers of sulphate in the plant cell membrane of the roots. At low concentration of the sulphate in the irrigating solution (300-600 ppm), the sulphate transporters in the plant's roots are activated or increased which facilitates the uptake of the chromate. However, at higher concentrations (>600 ppm), the sulphate carriers are saturated by the sulphate anion which competes for the plant transporters with the chromate anions and, hence, a decrease in the uptake of the metal is observed. Once in the roots, the translocation of chromium to the shoots is then limited by the concentration of the metal carrier ligands in the plant and/or the rate of the reduction process of $\mathrm{Cr}(\mathrm{VI})$ to $\mathrm{Cr}(\mathrm{III})$.

\section{Materials and Methods}

3.1. Chemicals and Reagents. Pure silica $\mathrm{SiO}_{2}$ was purchased from Dubai Sand Purification Co. Jebel Ali, Dubai. Potting soil (70\% organic content) was purchased from Blumen Erde from Syker Agrarberatungs, Skye, Germany. Ajman soil of $42 \%$ $\mathrm{CaCO}_{3}$ was taken from sandy hills behind Ajman City Centre (near the coordinates $25^{\circ} 23^{\prime} 45.4^{\prime \prime} \mathrm{N} 55^{\circ} 28^{\prime} 44.9^{\prime \prime} \mathrm{E}$ ). Standard chromium solutions (1000 ppm), hydrochloric acid (Conc. $\geq 37 \%$, trace analysis grade), and nitric acid (ACS Reagent $\geq 90.0 \%$ ) were purchased from Fluka Chemicals, Gillingham, UK. Reagent grade calcium oxide and sodium chromate were purchased from Panreac Química, Barcelona, Spain.

3.2. Instruments and Equipment. An ICP-OES instrument (Sequential Liberty AX, Varian, Mulgrave, Victoria, Australia) was used for measuring total chromium concentrations in soil and plant tissues, with the conditions recommended by the manufacturer $[6,7]$. A UV-Visible spectrometer (HI 93723, Hanna Instruments, Leighton, Buzzard, Bedfordshire, UK) was used to determine Cr(VI) in plants and soils. A pH Meter (PerpHecT Basic Benchtop Model Orion 320, Thermo-Orion, Loughborough, UK) was used for measuring the $\mathrm{pH}$ of soil and irrigation solutions.

3.3. Organic Content Effect: Growth Experiments. Simulated test soil was prepared using normal clean soil from Ajman, which has no detectable $\mathrm{Cr}(\mathrm{VI})$ content, $370 \pm 40 \mathrm{mg} / \mathrm{kg}$ of $\mathrm{Mn}$, and $4800 \pm 500 \mathrm{mg} / \mathrm{kg}$ of Fe, either pure or mixed with the potting soil as indicated in Table 1. Three groups of ten pots were filled with simulated test soil $(1600 \pm 100$ g per pot) with different organic contents (\%) (Table 1). Four seedlings of $P$. oleracea were grown in each pot and irrigated with deionised water for three weeks until considerable vegetation and rooting were achieved. Plants were grown at Ajman municipality nursery in partial shade (35\% shaded nursery, $65 \%$ of light intensity to pass through the net).

A stock solution of $200 \mathrm{ppm} \mathrm{Cr}(\mathrm{VI})$ [7] was prepared by diluting a concentrated solution of sodium chromate (at $10,000 \mathrm{ppm}$ of $\mathrm{Cr}(\mathrm{VI}))$. The pot sets of each soil with different organic contents were then divided into two subsets ( 5 pots each). One subset was irrigated with chromate solution $(8 \times 200 \mathrm{~mL}$ per pot $)$ over a period of ten days while the other subset was irrigated with the same quantity of deionised water as control groups.

The total organic content of the soil was determined using an adapted procedure [45]. In brief, a sample of the air-dried and sieved soil $(0.5 \mathrm{~g})$ was added to the $\mathrm{K}_{2} \mathrm{Cr}_{2} \mathrm{O}_{7}$ standard solution $(0.083 \mathrm{M}, 10 \mathrm{~mL})$ swirled at room temperature. Concentrated $\mathrm{H}_{2} \mathrm{SO}_{4}$ solution $(15 \mathrm{~mL}$ ) was then added to the mixture dropwise with gentle swirling and the mixture was heated under reflux for 1.0 hour. After cooling to room temperature, deionised water $(100 \mathrm{~mL})$ was added to the mixture with five drops of ferroin indicator 
TABLE 1: Soil composition with different organic contents.

\begin{tabular}{lcc}
\hline Organic content $(\%)$ & \multicolumn{2}{c}{ Soil composition } \\
& Potting soil (70\% organic matter content) $(\%)$ & Ajman soil (contains $42 \%$ CaCO $\left._{3}\right)(\%)$ \\
\hline $35 \pm 0.5$ & 50 & 50 \\
$17.5 \pm 0.5$ & 25 & 75 \\
$0.42 \pm 0.02$ & - & 100 \\
\hline
\end{tabular}

$\left(\mathrm{FeSO}_{4} \cdot 7 \mathrm{H}_{2} \mathrm{O}\right.$ and 1,10-phenanthroline monohydrate in water). The mixture was titrated with ferrous ammonium sulphate $(0.1 \mathrm{M})$ to reach an endpoint with the colour change from blue-green to violet-red. The same procedure was repeated for a blank solution (without the soil).

Organic carbon $(\mathrm{mg} / \mathrm{g})$ and organic content (\%) ofthe soil were then calculated from the following equations:

$$
\begin{aligned}
\operatorname{organic} \operatorname{carbon}(\mathrm{mg} / \mathrm{g}) & =18 \times C \times V \times \frac{\left(1-V_{1} / V_{2}\right)}{M}, \\
\operatorname{organic} \operatorname{content}(\%) & =\left(\frac{1}{5.8}\right) \times \operatorname{organic} \text { carbon }(\mathrm{mg} / \mathrm{g}),
\end{aligned}
$$

where $C(\mathrm{M})$ and $\boldsymbol{V}(\mathrm{mL})$ are the molar concentration and the added volume of the $\mathrm{K}_{2} \mathrm{Cr}_{2} \mathrm{O}_{7}$ solution, respectively, $V_{1}$ and $V_{2}(\mathrm{~mL})$ are the added volumes of ferrous ammonium sulphate for the sample and the blank, respectively, and $M$ (g) is the sample weight [45].

3.4. pH Effect: Growth Experiments. Six groups of twelve pots were filled with simulated test soil $(1200 \pm 100 \mathrm{~g}$ per pot) at a range of $\mathrm{pH}$ values as indicated in Table 2. Four seedlings of $P$. oleracea were grown in each pot and irrigated with deionised water for three weeks at the same conditions of the first experiment.

A stock solution of $200 \mathrm{ppm} \mathrm{Cr}(\mathrm{VI})$ was prepared by diluting a concentrated solution of sodium chromate (at $10,000 \mathrm{ppm}$ of $\mathrm{Cr}(\mathrm{VI})$ ). Then, the stock solution was divided into six solutions and the $\mathrm{pH}$ of each was adjusted with either $\mathrm{HCl}$ or $\mathrm{CaO}$ to match the $\mathrm{pH}$ value of each set of the soil pots $(6.0,7.0,7.3,7.6,8.0$, and 9.0). Buffer solutions were not used in order not to add anions or cations which may alter the uptake of $\mathrm{Cr}(\mathrm{VI})$. During the experiment, periodic checks of soil $\mathrm{pH}$ were carried out in order to maintain consistency. When considerable vegetation and rooting growth were observed at each level of $\mathrm{pH}$, the groups of twelve pots were divided into two sets of six-pot groups. The first six were irrigated with deionised water as a control and the other six were irrigated with $1200 \mathrm{~mL}$ of $200 \mathrm{ppm} \mathrm{Cr}(\mathrm{VI})$ with the matching $\mathrm{pH}$ at six doses over 12 days.

3.5. Sulphate Effect: Growth Experiments. Six groups of five pots were filled with synthetic soil consisting of $15 \% \mathrm{v} / \mathrm{v}$ potting soil and $85 \%$ of Ajman normal soil $(1500 \pm 100 \mathrm{~g}$ per pot). Four seedlings of $P$. oleracea were grown in each pot and irrigated with deionised water for three weeks at the same conditions of the previous experiments. When considerable vegetation and rooting growth were observed, each group of pots was irrigated with one of the solutions in

\begin{tabular}{|c|c|c|c|c|}
\hline \multirow[b]{2}{*}{$\begin{array}{l}\mathrm{pH} \text { of } \\
\text { soil }\end{array}$} & \multicolumn{4}{|c|}{ Soil composition } \\
\hline & $\begin{array}{c}\text { Pure } \\
\text { silica } \\
(\%) \\
\end{array}$ & $\begin{array}{c}\text { Potting soil }(70 \% \\
\text { organic matter } \\
\text { content })(\%)\end{array}$ & $\begin{array}{c}\text { Ajman soil } \\
\text { (contains } 42 \% \\
\left.\mathrm{CaCO}_{3}\right)(\%) \\
\end{array}$ & $\begin{array}{c}\mathrm{CaO} \\
(\%)\end{array}$ \\
\hline $6.0 \pm 0.1$ & 90 & 10 & - & - \\
\hline $7.0 \pm 0.1$ & 85 & 10 & 5 & - \\
\hline $7.3 \pm 0.1$ & 80 & 10 & 10 & - \\
\hline $7.6 \pm 0.1$ & 75 & 10 & 15 & - \\
\hline $8.0 \pm 0.1$ & - & 10 & 90 & - \\
\hline $9.0 \pm 0.1$ & - & 10 & 90 & $\sim 0.1$ \\
\hline
\end{tabular}

TABLE 2: Soil composition at different values of $\mathrm{pH}$.

Table 3 during a period of two weeks at six doses for a total of $1500 \mathrm{~mL}$ per pot. The plants were then harvested, separated into roots and shoots, washed, and dried.

3.6. Determination of Chromium Species. After considerable plant growth, the plants were pulled out of the soil using a water stream to remove the wedged soil among the roots. The plants were rinsed with deionised water and the length of the roots was measured for each plant as an indicator of the growth of the plant. The plants were divided into leaves, stems, and roots, and samples were dried at $65^{\circ} \mathrm{C}$ for 48 hours up to a constant weight, then ground using mortar and pestle. The samples were analysed in either one of two methods: (i) nitric acid digestion to determine the total chromium using ICP-OES or (ii) alkaline digestion to determine $\mathrm{Cr}(\mathrm{VI})$ in the sample using EPA method 3060A [46]. The extracted $\mathrm{Cr}(\mathrm{VI})$ was reacted with 1,5-diphenylcarbazide (ACS Reagent, SigmaAldrich, Gillingham, UK) in the presence of sulphuric acid and analysed using a UV-visible spectrometer at a wavelength of $540 \mathrm{~nm}$. Cr(III) was calculated by the subtraction of $\mathrm{Cr}(\mathrm{VI})$ from the total chromium in roots, leaves, and stems. Composite soil samples were taken from each pot, dried, sieved, and digested, and three replicates from each sample were analysed for $\mathrm{Cr}(\mathrm{VI})$ and total chromium.

3.7. Statistical Analysis. SPSS software (Version 15, SPSS UK Ltd., Woking, Surrey) was used for statistical analysis. Microsoft Excel (Microsoft UK, Reading, Berkshire) was used for the preparation of the graphs and for simple statistical operations. Results are reported in tables and graphs as with $95 \%$ confidence intervals calculated using Student's $t$-test. Analysis of variance (ANOVA, post hoc Tukey's test) between the means is used to identify if there are significant differences between means. 
TABLE 3: Concentrations of components of the irrigation solutions.

\begin{tabular}{lccc}
\hline Group \# & \# of pots & $\mathrm{Cr}(\mathrm{VI})$ as $\mathrm{Na}_{2} \mathrm{CrO}_{4}(\mathrm{ppm})$ & Sulphate as $\mathrm{Na}_{2} \mathrm{SO}_{4}(\mathrm{ppm})$ \\
\hline 1 & 5 & 0 & 0 \\
2 & 5 & 200 & 0 \\
3 & 5 & 200 & 300 \\
4 & 5 & 200 & 600 \\
5 & 5 & 200 & 1200 \\
6 & 5 & 200 & 1800 \\
\hline
\end{tabular}

\section{Conclusion}

In this study, the effect of soil organic content, $\mathrm{pH}$, and sulphate concentration on the uptake of $\mathrm{Cr}(\mathrm{VI})$ by $P$. oleracea was investigated. It was shown that as the organic matter content of the soil increases, the uptake of the chromium decreases due to the reduction of $\mathrm{Cr}(\mathrm{VI})$ to $\mathrm{Cr}$ (III) which has lower bioavailability. As for the $\mathrm{pH}$ effect, the results indicated that the uptake of chromium by $P$. oleracea is greatest at $\mathrm{pH}=8$, when the chromate anion is the dominant species. This speciation-dependent uptake suggested that the mechanism for the uptake of the chromate in $P$. oleracea resembles that of the sulphate anions. Hence, the effect of the sulphate concentration on the uptake of $\mathrm{Cr}(\mathrm{VI})$ by $P$. oleracea was investigated and it was shown that low concentrations $(300-600 \mathrm{ppm})$ of the sulphate in the soil enhance the uptake of the metal by the plant while high concentrations $(>600 \mathrm{ppm})$ inhibit it. In conclusion, this study further supports the hypothesis that $P$. oleracea is a suitable hyperaccumulator for remediation of chromium-polluted UAE soil, which has low organic content and an optimal $\mathrm{pH}$ at $7.9 \pm 0.1$ [7]. The process can be made more efficient by supplementing the soil with sulphate salts at low concentrations.

\section{Data Availability}

All data used to support the findings of this study are included in the article.

\section{Disclosure}

This paper represents the opinions of the authors and does not mean to represent the position or opinions of the American University of Sharjah.

\section{Conflicts of Interest}

The authors declare that they have no conflicts of interest.

\section{Acknowledgments}

The authors would like to acknowledge the logistic support of the American University of Sharjah (BCE) and Ajman Municipality. The work was also supported, in part, by the Open Access Program from the American University of Sharjah.

\section{References}

[1] T. Farkhondeh and S. Samarghandian, "The therapeutic effects of Portulaca oleracea L. in hepatogastric disorders," Gastroenterología y Hepatología (English Edition), vol. 42, no. 2, pp. 127-132, 2019.

[2] M. Iranshahy, B. Javadi, M. Iranshahi et al., "A review of traditional uses, phytochemistry and pharmacology of Portulaca oleracea L," Journal of Ethnopharmacology, vol. 205, pp. 158-172, 2017.

[3] E. Muszyńska and E. Hanus-Fajerska, "Why are heavy metal hyperaccumulating plants so amazing?" Biotechnologia, vol. 96, pp. 265-271, 2015.

[4] M. M. Lasat, "Phytoextraction of toxic metals," Journal of Environment Quality, vol. 31, no. 1, pp. 109-120, 2002.

[5] H. Okuhata, M. Masahiko, N. Takemoto et al., "Phytoremediation of $4,4^{\prime}$-thiodiphenol (TDP) and other bisphenol derivatives by Portulaca oleracea cv," Journal of Bioscience and Bioengineering, vol. 115, no. 1, pp. 55-57, 2013.

[6] A. Alyazouri, R. Jewsbury, H. Tayim, P. Humphreys, and M. H. Al-Sayah, "Applicability of heavy-metal phytoextraction in United Arab Emirates: an investigation of candidate species," Soil and Sediment Contamination: An International Journal, vol. 23, no. 5, pp. 557-570, 2014.

[7] A. H. Alyazouri, R. A. Jewsbury, H. A. Tayim, P. N. Humphreys, and M. H. Al-Sayah, "Phytoextraction of Cr(VI) from soil using Portulaca oleracea," Toxicological \& Environmental Chemistry, vol. 95, no. 8, pp. 1338-1347, 2013.

[8] N. Amer, Z. A. Chami, L. A. Bitar, D. Mondelli, and S. Dumontet, "Evaluation of Atriplex halimus, Medicago lupulina and Portulaca Oleracea for phytoremediation of $\mathrm{Ni}$, $\mathrm{Pb}$, and $\mathrm{Zn}$," International Journal of Phytoremediation, vol. 15, no. 5, pp. 498-512, 2013.

[9] E. M. Eid and K. H. Shaltout, "Bioaccumulation and translocation of heavy metals by nine native plant species grown at a sewage sludge dump site," International Journal of Phytoremediation, vol. 18, no. 11, pp. 1075-1085, 2016.

[10] M. M. Elshamy, Y. M. Heikal, and G. Bonanomi, "Phytoremediation efficiency of Portulaca oleracea L. naturally growing in some industrial sites, Dakahlia District, Egypt," Chemosphere, vol. 225, pp. 678-687, 2019.

[11] H. Hammami, M. Parsa, M. H. R. Mohassel, S. Rahimi, and S. Mijani, "Weeds ability to phytoremediate cadmium-contaminated soil," International Journal of Phytoremediation, vol. 18, no. 1, pp. 48-53, 2016.

[12] R. A. Kale, V. H. Lokhande, and A. B. Ade, "Investigation of chromium phytoremediation and tolerance capacity of a weed, Portulaca oleracea L. in a hydroponic system," Water and Environment Journal, vol. 29, no. 2, pp. 236242, 2015.

[13] S. Karbassi, M. Malek, T. Shahriari, and M. A. Zahed, "Uptake of metals by plants in urban areas," International Journal of Environmental Science and Technology, vol. 13, no. 12, pp. 2847-2854, 2016. 
[14] L. Midhat, N. Ouazzani, A. Hejjaj, A. Ouhammou, and L. Mandi, "Accumulation of heavy metals in metallophytes from three mining sites (Southern Centre Morocco) and evaluation of their phytoremediation potential," Ecotoxicology and Environmental Safety, vol. 169, pp. 150-160, 2019.

[15] H. P. Singh, P. Mahajan, S. Kaur, D. R. Batish, and R. K. Kohli, "Chromium toxicity and tolerance in plants," Environmental Chemistry Letters, vol. 11, no. 3, pp. 229-254, 2013.

[16] C. Cervantes, J. Campos-García, S. Devars et al., "Interactions of chromium with microorganisms and plants," FEMS Microbiology Reviews, vol. 25, no. 3, pp. 335-347, 2001.

[17] P. K. Das, B. P. Das, and P. Dash, "Hexavalent chromium induced toxicity and its remediation using macrophytes," Pollution Research, vol. 36, pp. 92-98, 2017.

[18] G. Choppala, N. Bolan, and J. H. Park, "Chromium contamination and its risk management in complex environmental settings," Advances in Agronomy, vol. 120, pp. 129-172, 2013.

[19] M. Shahid, S. Shamshad, M. Rafiq et al., "Chromium speciation, bioavailability, uptake, toxicity and detoxification in soil-plant system: a review," Chemosphere, vol. 178, pp. 513533, 2017.

[20] A. Shamshad, C. Cervantes, H. Lozatavera, and S. Avudainayagam, "Chromium toxicity in plants," Environment International, vol. 31, no. 5, pp. 739-753, 2005.

[21] A. K. Shanker, M. Djanaguiraman, and B. Venkateswarlu, "Chromium interactions in plants: current status and future strategies," Metallomics, vol. 1, no. 5, pp. 375-383, 2009.

[22] W. Ding, D. I. Stewart, P. N. Humphreys, S. P. Rout, and I. T. Burke, "Role of an organic carbon-rich soil and Fe(III) reduction in reducing the toxicity and environmental mobility of chromium(VI) at a COPR disposal site," Science of the Total Environment, vol. 541, pp. 1191-1199, 2016.

[23] N.-H. Hsu, S.-L. Wang, Y.-H. Liao, S.-T. Huang, Y.-M. Tzou, and Y.-M. Huang, "Removal of hexavalent chromium from acidic aqueous solutions using rice straw-derived carbon," Journal of Hazardous Materials, vol. 171, no. 1-3, pp. 10661070, 2009.

[24] Y. M. Tzou, M. K. Wang, and R. H. Loeppert, "Organic ligandenhanced photochemical reduction and immobilization of chromium(vi) on Tio2 particles in acidic aqueous media," Soil Science, vol. 169, no. 6, pp. 413-422, 2004.

[25] G. Choppala, A. Kunhikrishnan, B. Seshadri, J. H. Park, R. Bush, and N. Bolan, "Comparative sorption of chromium species as influenced by $\mathrm{pH}$, surface charge and organic matter content in contaminated soils," Journal of Geochemical Exploration, vol. 184, pp. 255-260, 2018.

[26] M. Taghipour and M. Jalali, "Effects of some industrial and organic wastes application on growth and heavy metal uptake by tomato (Lycopersicum esculentum) grown in a greenhouse condition," Environmental Science and Pollution Research, vol. 27, no. 5, pp. 5353-5366, 2019.

[27] M. Taghipour and M. Jalali, "Impact of some industrial solid wastes on the growth and heavy metal uptake of cucumber (Cucumis sativus L.) under salinity stress," Ecotoxicology and Environmental Safety, vol. 182, Article ID 109347, 2019.

[28] Y. M. Tzou, R. H. Loeppert, and M. K. Wang, "Light-catalyzed chromium(VI) reduction by organic compounds and soil minerals," Journal of Environmental Quality, vol. 32, no. 6, pp. 2076-2084, 2003.

[29] B. K. Mandal, R. Vankayala, and L. Uday Kumar, "Speciation of chromium in soil and sludge in the surrounding Tannery region, Ranipet, Tamil Nadu,” ISRN Toxicology, vol. 2011, Article ID 697980, 10 pages, 2011.

[30] J. Prokisch, B. Kovács, Z. Győri, and J. Loch, "Speciation of chromium from soil," Soil \& Environment, vol. 5, pp. 405-406, 1995.

[31] V. Vidayanti, D. N. Choesin, and I. Iriawati, "Phytoremediation of chromium: distribution and speciation of chromium in Typha angustifolia," International Journal of Plant Biology, vol. 8, no. 1, pp. 14-18, 2017.

[32] Z. L. Wang, H. Z. Zhang, Y. P. Wang, and W. H. Yu, "Soil pollution investigation of chromium slag contaminated site," Advanced Materials Research, vol. 430-432, pp. 812-815, 2012.

[33] L. M. de Oliveira, J. Gress, J. De et al., "Sulfate and chromate increased each other's uptake and translocation in ashyperaccumulator Pteris vittata," Chemosphere, vol. 147, pp. 36-43, 2016.

[34] L. M. de Oliveira, L. Q. Ma, J. A. G. Santos, L. R. G. Guilherme, and J. T. Lessl, "Effects of arsenate, chromate, and sulfate on arsenic and chromium uptake and translocation by arsenic hyperaccumulator Pteris vittata L," Environmental Pollution, vol. 184, pp. 187-192, 2014.

[35] A. Bonet, C. Poschenrieder, and J. Barcelo, "Chromium IIIiron interaction in Fe-deficient and Fe-sufficient bean plants. I. Growth and nutrient content," Journal of Plant Nutrition, vol. 14, no. 4, pp. 403-414, 1991.

[36] M. González-Alejandre, J. C. González-Cortés, Y. CarreónAbud, and M. Martínez-Trujillo, "Total chromium captured by maize (Zea mays) plants is increased by phosphate and iron supplementation in the soil," Communications in Soil Science and Plant Analysis, vol. 49, no. 5, pp. 615-625, 2018.

[37] N. Koçberber and G. Dönmez, "Chromium(VI) bioaccumulation capacities of adapted mixed cultures isolated from industrial saline wastewaters," Bioresource Technology, vol. 98, no. 11, pp. 2178-2183, 2007.

[38] M. Martínez-Trujillo and Y. Carreón-Abud, "Effect of mineral nutrients on the uptake of $\mathrm{Cr}(\mathrm{VI})$ by maize plants," New Biotechnology, vol. 32, no. 3, pp. 396-402, 2015.

[39] B. Ninagawa and S. Sumathi, "Uptake of chromium by Aspergillus foetidus," Journal of Material Cycles and Waste Management, vol. 7, no. 2, pp. 88-92, 2005.

[40] P. R. Shewry and P. J. Peterson, "The uptake and transport of chromium by barley seedlings (Hordeum vulgare L.)," Journal of Experimental Botany, vol. 25, no. 4, pp. 785-797, 1974.

[41] I. D. Kleiman and D. H. Cogliatti, "Uptake of chromate in sulfate deprived wheat plants," Environmental Pollution, vol. 97, no. 1-2, pp. 131-135, 1997.

[42] S. D. Lindblom, S. Abdel-Ghany, B. R. Hanson, S. Hwang, N. Terry, and E. A. H. Pilon-Smits, "Constitutive expression of a high-affinity sulfate transporter in Indian mustard affects metal tolerance and accumulation," Journal of Environmental Quality, vol. 35, no. 3, pp. 726-733, 2006.

[43] M. Schiavon, E. A. H. Pilon-Smits, M. Wirtz, R. Hell, and M. Malagoli, "Interactions between chromium and sulfur metabolism in Brassica juncea," Journal of Environmental Quality, vol. 37, no. 4, pp. 1536-1545, 2008.

[44] K. Appenroth, L. Alexandra, J. Gottfried, and G. Halina, "Modification of chromate toxicity by sulphate in duckweeds (Lemnaceae)," Aquatic Toxicology, vol. 89, no. 3, pp. 167-171, 2008.

[45] M. Radojevic and V. Bashkin, "Soil, sediment, sludge and dust analysis," in Practical Environmental Analysis, pp. 274-377, RSC Publishing, London, UK, 1999. 
[46] EPA, Method 3060A: Alkaline Digestion for Hexavalent Chromium, EPA, Washington, DC, USA, 1996, https://www. epa.gov/sites/production/files/2015-12/documents/3060a. pdf.2019. 